\title{
PERAN PROFESI GURU DALAM PENDIDIKAN
}

\author{
M. Riduan \\ Email: 2010111110001@ulm.ac.id \\ Program Studi Pendidikan Sejarah Fakultas Keguruan dan Ilmu Pendidikan \\ Universitas Lambung Mangkurat \\ Banjarmasin
}

\begin{abstract}
Abstrak
Profesi ialah suatu pekerjaan ataau jabatan yang menuntut keahlian tertentu. Guru merupakan suatu profesi, yang berarti suatu jabatan yang memerlukakan keahlian khusus sebagai guru dan tidak dapat dilakukan oleh sembarang orang diluar pendidikan. Guru menuntut peran sebagai teladan atau panuutan bagi peserta didiknya, dalam menjalakan tugasdan profesinya guru memiliki hak dan kewajiban yang harus dilaksanakan dan diperhatikan. Profesionalisme merupakan suatu sikap dari seorang profesional. Artinya sebuah termasuk yang menjelaskan bahwa setiap pekerjaan hendaknya dikerjakan oleh seseorang yang mempunyai keahlian dalam bidangnya atau profesinya. Dan kompetesi profesional guru adalah kemmpuan atau kewenangan guru dalam menjalankan profesi keguruannya, artinya guru yang melaksanakan profesinya dapat disebut sebagai guru yang kompeten dan profesionalnya.

Kata Kunci : propesi dan profesi guru, peran, hak dan kewajiaban guru, profesional guru , kompetensi profesional guru.
\end{abstract}

\section{PENDAHULUAN}

Profesi secara etemologi berasal dari kata professional (inggris) yang berasal dari bahasa latin profesus yang berarti "mampu atau ahli dalam suatu bentuk pekerjaan". Profesi dapat diartikan sebagai suatu pekerjaan atau jabatan yang menuntut keahlian, yang didapat melalui pendidikan dan latihan tertentu. Profesi juga diartikan sebagai suatu jabatan atau pekerjaan tertentu yang mensyaratkan pengetahuan dan keterampilan khusus yang diperoleh dari pendidikan akademik yang intensif. Jadi profesi adalah suatu pekerjaan atau jabatan yang menentut keahlian tetentu. Artinya suatu pekerjaan atau jabatan yang disebut 
profesi tidak dapat dipegang oleh sembarang orang, tetapi memerlukan persiapan melalui pendidikan dan pelatihan secara khusus (Musriadi, 2016: 27-30)

Profesi pada hakikatnya adalah suatu pernyataan atau suatu janji terbuka yang menyatakan bahwa seseorang itu mengabdikan dirinya pada suatu jabatan atau pelayanan karena orang tersebut merasa terpanggil untuk menjabat pekerjaan itu. Istilah profesi merupakan simbul dari suatu pekerjaan itu sendiri, profesi mengajar adalah suatu jabatan yang mempunyai kekhususan. Kekhususan itu merupakan kelengkapan mengajar atau keterampilan yang mengambarkan bahwa seseorang melakukan tugas mengajar, yaitu membimbing manusia (Musriadi, 2016:30)

Berdasarkan UU RI No14 tahun 2005 tentang Guru dan Dosen Paal 1, Guru adalah pendidik profesional dengan tugas utama mendidik, dan mengajar, membimbing, mengarahkan, melatih, menilai, dan mengevaluasi peserta didikpada pendidikan usia dini jalur pendidikan formal, pendidikan dasar, pendidikan menegah. Dosen adalah pendidik profesional dan ilmuan dengan tugas utama mentranformasikan, mengembangkan, dan menyebarluaskan, ilmu pengetahuan, telnologi, dan seni melalui pendidikan, penelitian, dan pengabdian kepada masyarakat.

Guru merupakan suatu profesi, yang berarti, suatu jabatan yang memerlukan keahlian khusus sebagai guru dan tidak dapat dilaukan oleh sembarang orang diluar pendidikan. Guru dapat melaksanakan evaluasi yang efektif serta mengunakan hasilnya untuk mengatahui peserta dan kemajuan siswa serta dapat melakukan perbaikan dan pengembangan. (Susanto, 2020: 13-18)

\section{PERAN GURU SEBAGAI SEBUAH PROFESI}

Guru digolongkan sebagai sebuah profesi, karena guru menentut peran sebagai teladan (panutan), ilmuan, motivator, dan bersikap bijak bagi peserta didiknya. Guru juga harus mampu menjadi sebagai sumber tempat bertanya peserta didiknya. Guru merupakan profesi tertua didunia seumur dengan keberadan manusia, profesi guru dianggap dapat dilakukan oleh semua orang. Guru adalah posisi yang strategis bagi pemberdayaan dan pembelajaran suatu bangsa yang tidak mungkin digantikan oleh unsur manapundalam kehidupan sebuah bangsa sejak dahulu. Semakin signifikannya keberadaan guru 
melaksanakan peran dan tugas semakain terjaminterciptanya kehandalan dan terbianya kesiapan seseorang. (Sosanto, 2020: 20).

Peran, hak, dan kewajiban guru merupakan sutu diantara profesi dibidang pendidikan, dalam Undang-undang No. 14 Tahun 2005, dikatakan guru adalah pendidik profesional dengan tugas utama mendidik, mengajar, membimbing, mengarahkan, melatih, menilai, dan mengevaluasipeserta didik, pada pendidikan anak usia dini jalut pendidikan formal, pendidikan dasar, pendidikan menegah. Guru dapat dirtikan sebagai seorang yang tugasnya terkait dengan upaya mencerdaskan kehidupan bangsa dan semua aspeknya, baik spiritual dan emosional, intelektual, fisikal, maupun aspek lainnya.

Tugas guru sebagai suatu profesi menuntut kepada guru untuk mengembangkan profesionalitas diri sesuai perkembangan ilmu pengetahuan dan teknologi, mendidik, mengajar, dan melatih anak didik adalah tugas guru sebagai suatu profesi,. Tugas guru sebagai pendidik berarti meneruskan dan mengambangkan nilai-nilaihidup kepada peserta didik. Tugas guru sebagai pelatih berarti mengembangkan keterampilan dan menerapkan dalam kehidupan demi masa depan peserta didik (Djamarah,2000:37).

Dalam menjalankan tugas dan profesinya, guru memiliki hak dan kewajibaan yang harus dilaksanakan dan diperhatikan. Hak guru berarti suatu yang harus didapatkan olehnya setelah ia melaksanakan sejumlah kewajiban sebagai guru. Kewajiban guru adalah suatu yang harus patut dilaksanakan oleh guru didalam menjalankan profesinya. (Susanto, 2020:37-44).

\section{GURU INDONESIA DAN TANTANGAN PROFESIONALISME}

Profesionalisme seorang guru mutlak diperlukan dalam kegiatan proses belajar mengajar, karena guru menjadi orat nadi dalam keberhasialan proses tersebut. Guru dinyatakan profesional jika memenuhi beberapa persyaratan, diantaranya: 1) Profesionalisme profesi keguruan. Pada dasarnya pengajaran merupakan bagian profesi yang memiliki ilmu ataupun teorikal, keterampilan, dan mengharapkan ideologi profesional tersendiri. Oleh sebab itu seseorang yang bekerja diintintut pendidikan dengan tugas mengajar, jika diukur dari teori dan prakteksebagai suatu pengetahuan yang mendasari guru juga merupakan sebagai profesi lain, 2) Otoritas profesionalisme guru, disiplin profesi keguruan dengan penuh keringat, kecekatan dan mengunakan metode yang bervariasi 
dalam mendidik anak-anak. Pendidikan profesionalisme memberi bantuan sampai tuntas kepada anak didik. Guru yang profesiaonal tidak hanyaa berkonsentrasi pada materi pelajaran tetaapi juga pada memperhatikan stuai-situasiertentu. (Muizzuddin, 2019 Vol. 7 No. 1 ).

Kempetensi profesional guru ialah kemampuan dan kewenanagan guru dalam menjalankan profesinya dapat disebut guru yang kompeten dan profesional. Kompetensi profesional merupakan pekerjaan yang hanya dapat dilakukan oleh seorang yang mempunyai kualifikasi akedemik, kompetensi dan sertifikat pendidikan sesuai dengan persyaratan untuk setiap jenis dan jenjang pendidikan tertentu.

Kompetensi profesional merupakan kemampuan dasar yang harus dimiliki oleh guru. Ada beberapa pandangan ahli tentang kompetensi profesional guru. Menurut Cooper (1984:15) komponen kompetisi dasar yakni : a. Mempunyai pengetahuan tentang belajar dan tingkah laku manusia, b. Mempunyai pengetahauan dan menguasai bidang studi yang dibinanya, c. Mempunyai sikap yang tepat tentang diri sendiri, sekolah, teman sejawat, bidang studi yang dibinanya, d. Mempunyai keterampilan dan teknik mengajar. (Susanto, 2020: 63).

\section{SIMPULAN}

Profesi secara etimologi berasal dari kata profession(inggris) yang berasal dari bahasa latin profesus yang berarti "mampu atau ahli dalam suatu bentuk pekerjan". Profesi dapat diartikan sebagai suatu pekerjan atau jabatan yang menuntut keahlian, yang didapat melalui pendidikan dan latihan tertentu, menurut persayatan khusus memiliki tanggung jawab dan kode etik tertentu. Profesi guru adalah pendidik profesional dengan tugas utama mendidik, mengajar, membimbing, mengarahkan, melatih, menilai, dan mengevaluasi peserta didik pada pendidikan anak usia dini jalur pendidikan formal, pendidikan dasar, pendidikan menegah. Guru merupakan suatu profesi, berarti suatu jabatan yang memerlukan keahlian khusus sebagai guru dan tidak dapat dilakukan oleh sembarang orang diluar bidang pendidikan. Hak guru berarti suatu yang harus didapatkan oelhnya setelah ia melaksanakan sejumlah kewajiban guru. Kewajiban guru adalah suatu yang harus dilaksanakan oleh guru dalam menjalankan profesinya. Profesionalisme ialah sikap dari sebuah termasuk yang menjelaskan pekerjaan hendaklah dikerjakan dengan keahlian dan 
bidangnya atau profesinya. Kompetesi profesional merupakan pekerjaan yang hanay dapat dilakukan oleh seorang yang mempunyai lualifikasi akedemik, komptensi dan serttifikat pendidikan sesuai dengan persyaratan untuk setiap jenis dan jenjang pendidikan tertentu.

\section{REFERENSI}

Efendi, I., Prawitasari, M., \& Susanto, H. (2021). Implementasi Penilaian Pembelajaran Pada Kurikulum 2013 Mata Pelajaran Sejarah. Prabayaksa: Journal of History Education, 1(1), 21-25.

Susanto, H. (2020). Profesi Keguruan. Banjarmasin: FKIP Universitas Lambung Mangkurat.

Susanto, H., \& Akmal, H. (2018). Efektivitas Penggunaan Aplikasi Pembelajaran Berbasis Mobile Smartphone Sebagai Media Pengenalan Sejarah Lokal Masa Revolusi Fisik Di Kalimantan Selatan Pada Siswa Sekolah Menengah Atas. HISTORIA: Jurnal Program Studi Pendidikan Sejarah, 6(2), 197-206.

Susanto, H., Irmawati, I., Akmal, H., \& Abbas, E. W. (2021). Media Film Dokumenter Masuknya Islam Ke Nusantara dan Pengaruhnya Terhadap Keterampilan Berpikir Kritis Siswa. HISTORIA: Jurnal Program Studi Pendidikan Sejarah, 9(1).

Syaharuddin, S., \& Susanto, H. (2019). Sejarah Pendidikan Indonesia (Era Pra Kolonialisme Nusantara sampai Reformasi). Banjarmasin: FKIP Universitas Lambung Mangkurat. 